\title{
Challenges to the Adoption of Agricultural Innovations: The Case of Yam Minisett Technology in Kwara State, Nigeria
}

\author{
Kemi F. Omotesho*, Adedamola V. Adetayo, Adeniyi F. Akinrinde and Deborah A. Olabode
}

Department of Agricultural Extension and Rural Development, University of Ilorin, PMB 1515 Ilorin, Nigeria

\begin{abstract}
This study analysed the challenges to the adoption of the Yam Minisett Technology (YMT). Specifically, the study assessed the level of adoption of the technology; identified the areas of training need in its use; identified the reasons for non-adoption by non-adopters as well as the constraints faced by adopter farmers in its use. The determinants of farmers' adoption were also investigated. A four-stage sampling procedure was used to select 205 respondents on whom an interview schedule was administered. Descriptive statistics, Probit Regression Analysis and Pearson's Product Moment Correlation, were used to analyse data. Result reveals that the farmers were mostly males (71.2\%), middle-aged (50.7years,) with an average of 28 years of farming experience. Only 58.5 percent of the farmers had adopted the YMT. Training was most required in the preparation of minisett dust and insecticide application (MWDS=3.58). Reasons for nonadoption of the technology included wrong perception of the technology, low technological know-how and increased production cost with mean scores of 2.92. High cost of production (MS=2.57), unavailability and poor quality of dust and insecticides $(\mathrm{MS}=2.08)$ and Poor training $(\mathrm{MS}=2.01)$ were major challenges faced by the adopters. At $\mathrm{p}<0.05$, frequency of extension contact $(\beta=0.209)$ and membership of farmer-groups $(\beta=0.562)$ significantly influenced adoption. The study concluded by highlighting the determinants as well as challenges to the adoption of the technology. Recommendations include increase in the frequency of extension visit, adequate sensitisation and training, and provision of needed accompanying materials as measures to ensure the adoption of innovations in the study area.

Received | July 11, 2019; Accepted | June 12, 2020; Published | August 6, 2020

*Correspondence | Kemi F. Omotesho, Department of Agricultural Extension and Rural Development, University of Ilorin, PMB 1515 Ilorin, Nigeria; Email: kfomotesho@gmail.com, omotesho.kf@unilorin.edu.ng

Citation | Omotesho, K.F., A.V. Adetayo, A.F. Akinrinde and D.A. Olabode. 2020. Challenges to the adoption of agricultural innovations: The case of yam minisett technology in Kwara State, Nigeria. Sarhad Journal of Agriculture, 36(3): 806-814.

DOI | http://dx.doi.org/10.17582/journal.sja/2020/36.3.806.814

Keywords $\mid$ Adoption, Compatibility, Diffusion, Innovation, Training
\end{abstract}

\section{Introduction}

A griculture remains the mainstay of the economy for many underdeveloped countries of the world. In Nigeria, it is the source of livelihood of over 70 percent of the population (FAO, 2018). As stated in the overall national policy of the country, the Economy Recovery Growth Plan (ERGP), agriculture is the road map of the country out of economic recession and provides the sustainable means of diversifying the country's economy from its over-dependence on the oil sector (Federal Government of Nigeria, 2017). Unfortunately,Nigeriahas notbeen able to significantly grow its agricultural sector with consequences for its food security. A major challenge to meaningful growth in the Nigerian agricultural sector is the level of technology use among the millions of small-scale resource-poor farmers that characterise the sector. The use of improved agricultural technologies is a major approach to increasing agricultural productivity and promoting food and livelihood security. With fifteen (15) agricultural research institutes, seventeen (17) 
Colleges of Agriculture and over 50 public and private universities with Faculties of Agriculture (Omotesho and Falola, 2014; National Cereal Research Institute, 2018; National Universities Commission, 2019), agricultural innovation is constantly being churned out in Nigeria. However, innovations in agricultural development are of little or no worth until they can be put to use for the economic and social well-being of the rural populace.

Agricultural innovations are often adopted slowly, and some aspects of the adoption process remain poorly understood in spite of being seen as an important route out of poverty in most of the developing countries (Simtowe, 2011). This is a serious gap that must be bridged if the problem of low technology adoption among farmers is to be addressed, and agricultural productivity improved. Farmers continue to hold on to several outdated traditional practices and methods which are often characterised by low productivity. A good example is found in the propagation of yam (Dioscorea sp.) in Nigeria.

Yam is an important root and tuber crop, especially in West Africa, where it contributes over 2000 dietary calories every day for over 60 million people (FAO, 2006). It is the second most important tropical root crop in West Africa after Cassava (Osunde, 2008). Osunde (2008) further observed that West Africa accounts for about 90 - 95\% of the world's production with Nigeria, producing about $70 \%$ of that quantity. Nigeria is the worlds' largest producer of yam with about $71-75 \%$ of the world production followed by Ghana, Cote d' Ivoire, Benin and Togo (FAO, 2006). While current production fairs well in meeting the domestic demand, foreign exchange earning opportunities have been poorly explored.

Traditional methods of yam propagation in Nigeria belabours farmers with high cost and difficulty in the acquisition of planting materials, and fail to produce uniform sized and standard tubers required by international markets. The methods include the milking method, Anambra system, planting cut setts and planting of small whole tubers (Aighewi et al., 2015). In these methods, the farmers need to keep about one-third of their yearly harvest in order to produce seed tubers for replanting in the following season. The improved methods of propagating yam include the botanic yam seed, yam minisett technology (YMT), vine cuttings for seed yam production, tissue and organ culture method of producing seed yams, aeroponics systems, and the temporary immersion bioreactor system (Maroya et al., 2014; Aighewi et al., 2015; Balogun et al., 2015). The National Root Crop Research Institute (NRCRI) and the International Institute of Tropical Agriculture (IITA) developed the Yam Minisett Technology (YMT) as a rapid means of multiplying yam germplasm (Oguntade et al., 2010). It explores the ability of every section of yam tubers to develop buds and sprout as long as a portion of the periderm is included. YMT does not require elaborate laboratory procedures or scientific expertise as a trained farmer can carry it out independently. The YMT was extensively promoted among farmers in Nigeria. However, over a decade after this breakthrough in research, farmers continue to use the traditional methods in spite of the advantages of the YMT.

The theory of diffusion of innovation (Rogers, 2003) provides a foundation to the understanding of the process of innovation diffusion and its adoption. The process which entails five stages (awareness, interest, trial, evaluation, and adoption) does not happen simultaneously for all in any given society and hence the idea of adopter categories (innovators, early adopters, early majority, late majority and the laggards). The theory also identifies characteristics of innovations which have a bearing on their adoption (relative advantage, compatibility, complexity, trialability, and observability). Studies have reported the effect of factors such as individuals socio-economic characteristics (age, level of education, income, and number of years of farming experience etc.) in their propensity to adopt innovation (Muhammed-Lawal et al., 2014). In addition, innovation more often than not, involves technicalities which require training of new entrants. The case of agricultural innovation is more so, giving the low literacy level reported among farmers in developing countries. In addition, the perception of farmers of an idea is fundamental to their judgment of it. Finally, it is possible that farmers face other challenges which either prevents them from adopting innovation however good or continue to hinder the maximisation of the benefits offered by the innovation (Saror et al., 2009). It is based on the preceding arguments that the study set out to:

1. Examine the adoption of YMT among farmers in Kwara State, Nigeria;

2. Identify areas of training need on YMT among farmers; 
3. Identify the reasons for the non-adoption of YMT by non-adopter farmers; and

4. Identify the constraints to the use of YMT by the farmers.

The hypotheses of this study were stated as follows: $\mathrm{HO}_{1}$ : Selected socio-economic characteristics of yam farmers do not affect their adoption of YMT.

$\mathrm{HO}_{2}$ : There is no significant relationship between farmers' training need on YMT and their adoption of the technology.

\section{Materials and Methods}

\section{The study area}

The study was Carried out in Kwara State, Nigeria. The state lies between latitudes $7^{\circ} 45^{\prime} \mathrm{N}$ and $9^{\circ} 30^{\prime} \mathrm{N}$ and longitudes $2^{\circ} 30^{\prime} \mathrm{E}$ and $6^{\circ} 25^{\prime} \mathrm{E}$. With a population of 3.19 million and a total land mass of $36,825 \mathrm{KM}^{2}$ (National Population Commission (NPC), the state has an estimated figure of 524,837 rural farm families (International Fund for Agricultural Development (IFAD, 2012). Kwara State is primarily agrarian and crops cultivated in the state include yam, cassava, maize, sorghum, millet, onions, beans, and rice. Yam production in the state was at 694.01000 metric tons in the year 2000 and fell to 328.01000 metric tons in 2005 accounting for about $1.34 \%$ of the total yam production in the country Kwara State Agricultural Development Project (KWADP, 2005).

\section{Sampling procedure and sample size}

A four-stage sampling procedure was used to select respondents for the study. The first stage was the purposive selection of Zones $\mathrm{A}$ and $\mathrm{D}$ out of the four ADP zones in the state. The selected zones are the hub of yam production in the state. The second stage was the random selection of $50 \%$ of blocks in the selected ADP zones. In the third stage, $50 \%$ of the cells from the selected blocks were randomly selected. The final stage involved the random selection of five (5) yam farmers from each cell. A summary of this procedure is provided in Table 1.

\section{Data collection and analysis}

Data collection was done with the aid of a structured interview schedule and subjected to both descriptive and inferential statistical tools. Descriptive statistics, the Probit regression analysis and the Pearson's Product Moment Correlation.

The probit equation for the purpose of the study is presented as:

$$
Y=\beta_{0}+\beta X_{1}+\beta X_{2}+\beta X_{3}+\ldots \ldots \ldots \ldots \beta X_{7}+\mu
$$

Where;

$Y=$ dependent variable of the study (Farmer's adoption of YMT). Measured using the adoption stages (Rogers, 1995) which are Awareness $=1$, Interest=2, Evaluation=3, Trial=4, and Adoption=5. For the purpose of analysis, adoption was treated as a binary variable. Respondents within the stages of awareness to trial (1-4) were categorised as nonadopters. Only respondents in the $5^{\text {th }}$ stage (adoption) were categorised as adopters.

$X_{1}-X_{7}=$ socio-economic characteristics of the farmers (Age: was measured in years, Household size: was measured as the total number of people living under the same roof and eating from the same pot, Level of education: was measured as the number of years spent in school, Contact with extension agent: was measured as the number of extension contact in the immediate past 6 months, Farm Size: was measured in acres, Total Annual Income: was measured in naira, Membership of Famer-group: was measured as a dummy variable 1 if yes, 0 if otherwise).

$\beta=$ the coefficient to be estimated; $\mu=$ the error term.

Training Needs of Farmers on YMT was determined using the Borich's Needs Assessment Model. According to Borich (1980), training needs (which is taken as the Mean Weighted Discrepancy Score MWDS) can be calculated using the following formula:

Training need $(\mathrm{MWDS})=$ (Importance score Competence score $) \times$ Mean of Importance

For the purpose of this study, however, a threshold of two thirds (2/3) of the mean weighted discrepancy score (MWDS) was adopted for the establishment of respondents' need for training in any particular activity of YMT.

A four-point Likert scale was used in the measurement of the respondents' perceived importance of each YMT activity and also the level of the respondents' competence in carrying out each of the listed YMT activities. 
Table 1: Sampling procedure and sample size.

\begin{tabular}{|lllll}
$\begin{array}{l}\mathbf{5 0 \%} \text { of KWADP zones } \\
\text { (purposively selected) }\end{array}$ & $\begin{array}{l}\mathbf{5 0 \%} \text { of blocks in each zone } \\
\text { (randomly selected) }\end{array}$ & $\begin{array}{l}\mathbf{5 0 \%} \text { of cells in each block } \\
\text { (randomly selected) }\end{array}$ & $\begin{array}{l}\mathbf{5} \text { yam farmers from each } \\
\text { cell (randomly selected) }\end{array}$ & $\begin{array}{l}\text { Total number of } \\
\text { respondents }\end{array}$ \\
\hline A & $8(4)$ & $32(16)$ & 80 & 205 \\
\hline D & $12(6)$ & $50(25)$ & 125 & \\
\hline
\end{tabular}

Source: Author, 2018.

Reasons for Non-Adoption of YMT was measured using a 4-point Likert scale. A four-point Likert-type scale was also used to measure the constraints to the use of YMT.

\section{Results and Discussion}

Socio-economic variables of respondents

This section presents the socio-economic characteristics of the yam farmers. The results are presented in Table 2.

The results show that majority $(82.5 \%)$ of the respondents were within the physically active age group of 30-59 years. With an average age of 50.7 years and a modal age class of 50-59 years, the result implies that majority of the respondents were still energetic enough to engage in yam production. However, while over $54 \%$ of the farmers were over 50 years old, only $11.7 \%$ fall within Nigeria's age classification for youths. The implication of this finding is the dwindling involvement of youths in yam farming and agricultural production as a whole. Odinwa et al. (2011) also reported a similar age classification among yam farmers in the eastern part of the country. As shown in Table 2, majority of the yam farmers in Kwara State were male (71.2\%). This is in agreement with the findings of Bolarinwa and Oladeji (2009) who observed that yam is a "men's crop" in Africa because it is labour intensive. The average household size of the respondents was about seven members. The table also reveals the low level of education with an average of two years spent in school. According to Uaine et al., 2009, the acceptance of improved technology is facilitated by education. It can be expected that the low level of education may impede the farmers' adoption of innovation.

With an average of 27.8 years of farming experience, the farmers were quite experienced in yam cultivation. In spite of the importance of training to the dissemination of new technology, Table 2 reveals that only 27.3 percent of the respondents had received training on the technology. Also, $34 \%$ of the respondents had not had any contact with extension agent in the immediate past six months period to the time of the field survey and the mean number of extension contact over the same period was less than two. Nnadi and Akwiwu (2007) established a relationship between the adoption of innovation and frequency of extension contact.

\section{Level of adoption of the YMT}

This section discusses the result on the stages of adoption of the respondents. The results are presented in Table 3.

Even though the YMT had been deployed to farmers in Nigeria for over a decade, Table 3, reveal that 7.8 percent of the farmers dropped the technology at the awareness stage. Another 16.1 percent and 6.4 percent went on to the interest and the evaluation stages, respectively. In addition, 11.2 percent of the farmers tried the technology and went back to their former practices, while 58.5 percent of the respondents adopted the technology and were using it as at the time of the field survey. Bolarinwa and Oladeji 2009, also reported only a fair level of adoption of the YMT in Southwestern Nigeria.

\section{Training needs of farmers on YMT}

This section discusses the training needs of the farmers on YMT. Discussion under this section covers respondents perceived level of importance of YMT activities, their level of competence in the activities and the distribution of the respondents by their training needs. The results are presented in Tables 4, 5 and 6 , respectively.

Table 4 shows the respondents' perceived importance of YMT activities. The respondents perceived all the YMT activities as important. It is also revealed from the result that the mean importance score of all the YMT activities was high (greater than 3.0), indicating a high level of importance attached to the YMT activities by the farmers. 
Table 2: Socio-economic variables $(n=205)$

\begin{tabular}{|lllllll} 
Variables & $\begin{array}{c}\text { Fre- } \\
\text { quency }\end{array}$ & $\begin{array}{l}\text { Percent- } \\
\text { ages }\end{array}$ & Mean & S.D & Min & Max \\
\multicolumn{2}{l}{ Age (in years) } & & & & & \\
$30-39$ & 24 & 11.7 & 50.7 & 10.2 & 30.0 & 75.0 \\
$40-49$ & 69 & 33.7 & & & & \\
$50-59$ & 76 & 37.1 & & & & \\
$60-69$ & 23 & 11.2 & & & & \\
$70-79$ & 13 & 6.3 & & & &
\end{tabular}

Sex

Male $\quad 146 \quad 71.2$

$\begin{array}{lll}\text { Female } \quad 59 & 28.8\end{array}$

Family size

\begin{tabular}{lcccccc}
$2-4$ & 46 & 22.4 & 6.6 & 2.6 & 2.0 & 13.0 \\
$5-7$ & 96 & 46.8 & & & & \\
$8-10$ & 43 & 21.0 & & & & \\
$11-13$ & 20 & 9.8 & & & & \\
\multicolumn{7}{l}{ Years spent in school } \\
0 & 153 & 74.6 & .0 & 4.6 & 0.0 & 17.0 \\
$1-4$ & 19 & 25.9 & & & & \\
$5-9$ & 14 & 42.0 & & & & \\
$10-14$ & 12 & 28.8 & & & & \\
$>14$ & 07 & 34.0 & & & &
\end{tabular}

Farm size (Acre)

1-4 $\quad 100 \quad 48.8$

5-8 $\quad 56 \quad 27.3$

9-12 $39 \quad 19.0$

$>12 \quad 10 \quad 4.9$

$\begin{array}{llll}5.5 & 3.9 & 1.0 & 15.0\end{array}$

Annual farm income

\begin{tabular}{|c|c|c|c|c|c|c|}
\hline $\begin{array}{l}100,000- \\
300,000\end{array}$ & 97 & 47.3 & \multirow{5}{*}{$\begin{array}{l}\stackrel{n}{0} \\
\hat{0} \\
\sigma \\
\vec{f}\end{array}$} & \multirow{5}{*}{ 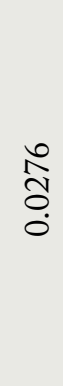 } & \multirow{5}{*}{$\begin{array}{l}8 \\
8 \\
8 \\
8 \\
8\end{array}$} & \multirow{5}{*}{$\begin{array}{l}8 \\
8 \\
8 \\
8 \\
-1\end{array}$} \\
\hline $\begin{array}{l}300,001- \\
500,000\end{array}$ & 43 & 21.0 & & & & \\
\hline $\begin{array}{l}500,001- \\
700,000\end{array}$ & 28 & 13.7 & & & & \\
\hline $\begin{array}{l}700,001- \\
900,000\end{array}$ & 26 & 12.7 & & & & \\
\hline$>900,000$ & 11 & 5.4 & & & & \\
\hline \multicolumn{7}{|c|}{ Farming experience } \\
\hline $15-23$ & 76 & 37.1 & 27.8 & 9.3 & 15.0 & 62.0 \\
\hline $24-32$ & 87 & 42.4 & & & & \\
\hline $33-41$ & 23 & 11.2 & & & & \\
\hline $42-50$ & 10 & 4.9 & & & & \\
\hline$>50$ & 9 & 4.4 & & & & \\
\hline
\end{tabular}

Membership of farmers' group

$\begin{array}{lll}\text { Yes } & 133 & 64.9\end{array}$

$\begin{array}{lll}\text { No } & 72 & 35.1\end{array}$

Training on YMT

$\begin{array}{lll}\text { Yes } & 56 & 27.3 \\ & 149 & 72.7\end{array}$

Frequency of extension contact

$\begin{array}{lllllll}0 & 70 & 34.1 & 1.4 & 1.2 & 0.0 & 4.0 \\ 1-2 & 96 & 46.8 & & & & \\ 3-4 & 39 & 19.1 & & & & \end{array}$

Source: Field survey, 2018. S.D: Standard deviation; Min: Minimum; Max: Maximum.
Table 3: Respondents' distribution by their stages of adoption.

$\begin{array}{lll}\text { Stages of adoption } & \text { Frequency } & \text { Percentage } \\ \text { Awareness } & 16 & 7.8 \\ \text { Interest } & 33 & 16.1 \\ \text { Evaluation } & 13 & 6.3 \\ \text { Trial } & 23 & 11.2 \\ \text { Adoption } & 120 & 58.5\end{array}$

Source: Field survey, 2018.

Table 5 reveals the level of competence of farmers on YMT activities. Result shows that the farmers were poor in carrying out all the YMT activities. With a mean competence score of less than 2.0 in all the YMT activities, it could be deduced that the farmers had a low level of competence in using the YMT.

Table 6 shows that the farmers need training in every one of the listed YMT activities with the area with the most severe need being selection of suitable tubers and the least severe area being the application of minisett dust and insecticides. This finding is maybe as a result of the report in Table 2 that only 27.3 percent of the farmers had benefited from training on the technology.

\section{Reasons for non-adoption of YMT by the farmers}

This section discusses the reasons for non-adoption of the Technology by the non-adopter farmers in the study area. The results are presented in Table 7.

Results presented in Table 7 shows that respondents had not adopted the YMT as they were constrained by low technological know-how $(\mathrm{MS}=2.95)$ and high cost of labour $(\mathrm{MS}=2.95)$. General increased cost involved in using YMT (MS=2.92) and the timeconsuming nature of the preparation of the minisetts (MS=2.91) were also identified as major reasons for the non-adoption of yam minisett technology. Some of the other reasons for non-adoption of the technology included failures experienced at the trial stage (MS=2.88), poor training in the planting of the minisetts $(\mathrm{MS}=2.88)$, tedious nature of the technology $(\mathrm{MS}=2.81)$, and the small-sized tubers $(\mathrm{MS}=2.81)$. The reason for non-adoption, which recorded the least score was the poor compatibility of the technology with farmer's existing practice (MS=1.86). In all, the reasons can be categorised into three groups. The first had to do with technological know-how (Knowledge and skill of minisett preparation and its planting). The second group involved the higher level of resources 
Table 4: Farmers' perceived importance of YMT activities ( $n=205)$.

$\begin{array}{llllllll}\text { YMT Activities } & \text { V.I F(\%) } & \text { I F(\%) } & \text { M.I F(\%) } & \text { N.I F(\%) } & \text { Score } & \text { MS } & \text { Remark } \\ \text { Tuber selection } & 128(62.4) & 65(31.7) & 9(4.4) & 3(1.5) & 728 & 3.55 & \text { I } \\ \text { Cutting into minisett } & 92(44.9) & 94(45.9) & 16(7.8) & 3(1.5) & 685 & 3.34 & \text { I } \\ \text { Air drying } & 80(39) & 92(44.9) & 30(14.6) & 3(1.5) & 659 & 3.21 & \text { I } \\ \text { Application of minisett dust and insecticides } & 54(26.3) & 116(56.6) & 28(13.7) & 7(3.4) & 627 & 3.06 & \text { I } \\ \text { Curing } & 75(36.6) & 95(46.3) & 28(13.7) & 7(3.4) & 648 & 3.16 & \text { I } \\ \text { Planting Spacing. } & 66(32.2) & 112(54.6) & 21(10.2) & 6(2.9) & 648 & 3.16 & \text { I } \\ \text { Planting depth } & 63(30.7) & 116(56.6) & 21(10.2) & 5(2.4) & 647 & 3.15 & \text { I } \\ \text { Time of planting } & 97(47.3) & 87(42.4) & 20(9.8) & 1(0.5) & 690 & 3.37 & \text { I } \\ \text { Intercropping } & 66(32.2) & 115(56.1) & 21(10.2) & 3(1.5) & 654 & 3.19 & \text { I }\end{array}$

Source: Field survey, 2018. I: Important; Benchmark: Important: Mean score > 2.00, Not Important: Mean score < 2.00

Table 5: Competence of farmers on YMT activities $(n=205)$.

$\begin{array}{llllllll}\text { Likert items } & \text { Poor F(\%) } & \text { Fair F(\%) } & \text { Good F(\%) } & \text { Excellent F(\%) } & \text { Score } & \text { MS } & \text { Remark } \\ \text { Tuber selection } & 130(63.4) & 66(32.2) & 6(2.9) & 3(1.5) & 292 & 1.42 & \text { P } \\ \text { Cutting into minisett } & 92(44.9) & 101(49.3) & 10(4.9) & 2(1) & 332 & 1.62 & \mathrm{P} \\ \text { Air drying } & 80(39) & 107(52.2) & 15(7.3) & 3(1.5) & 351 & 1.71 & \mathrm{P} \\ \text { Application of minisett dust and insecticides } & 56(27.3) & 123(60) & 19(9.3) & 7(3.4) & 387 & 1.89 & \mathrm{P} \\ \text { Curing } & 64(31.2) & 120(58.5) & 16(7.8) & 5(2.4) & 372 & 1.81 & \mathrm{P} \\ \text { Planting Spacing. } & 70(34.1) & 118(57.6) & 10(4.9) & 7(3.4) & 364 & 1.78 & \mathrm{P} \\ \text { Planting depth } & 85(41.5) & 107(52.2) & 10(4.9) & 3(1.5) & 341 & 1.66 & \mathrm{P} \\ \text { Time of planting } & 76(37.1) & 110(53.7) & 18(8.8) & 1(0.5) & 354 & 1.73 & \mathrm{P} \\ \text { Intercropping } & 66(32.2) & 117(57.1) & 16(7.8) & 6(2.9) & 372 & 1.81 & \mathrm{P}\end{array}$

Source: Field Survey, 2018. Benchmark: Good: Mean score > 2.00, Poor; Mean score < 2.00

needed to use the technology (capital, labour, and time). The last group of reasons had to do with the farmers' wrong perception of the technology.

Table 6: Respondents training need in the use of YMT.

\begin{tabular}{|c|c|c|c|c|}
\hline YMT Activities & $\begin{array}{l}\text { Mean of } \\
\text { importance }\end{array}$ & $\begin{array}{l}\text { Mean of } \\
\text { competency }\end{array}$ & MWDS & Rank \\
\hline Tuber selection & 3.55 & 1.42 & 7.56 & 1 st \\
\hline Cutting into minisett & 3.34 & 1.62 & 5.74 & 2nd \\
\hline Time of planting & 3.37 & 1.73 & 5.53 & $3 \mathrm{rd}$ \\
\hline Air drying & 3.21 & 1.71 & 4.82 & 4th \\
\hline Planting depth & 3.15 & 1.66 & 4.69 & 5 th \\
\hline Intercropping & 3.19 & 1.81 & 4.40 & 6th \\
\hline Planting Spacing. & 3.16 & 1.78 & 4.36 & 7 th \\
\hline Curing & 3.16 & 1.81 & 4.27 & 8 th \\
\hline $\begin{array}{l}\text { Application of minisett } \\
\text { dust or insecticides }\end{array}$ & 3.06 & 1.89 & 3.58 & 9th \\
\hline
\end{tabular}

Source: Field survey, 2018.

\section{Challenges to the use of YMT by the farmers}

This section discusses the constraints encountered by farmers who had adopted and were using the YMT.
Results presented in Table 8 reveals, in order of severity, the constraints to the use of YMT by the respondents who had adopted the technology. Increased production cost (MS=2.57) was the most severe constraint to the use of YMT. Scarcity of dust and insecticide coupled with their adulteration ranked second in order of severity with a mean score of $\mathrm{MS}=2.08$. Other constraints included poor level of training in the planting of minisetts leading to failure of the crops (2.01), Poor knowledge and skill in the preparation of minisetts (1.99), heavy demand on farmers' time (1.98), poor markets (1.94) tediousness of activities involved in the preparation and planting of minisetts (1.91) and poor level of compatibility with farmers' existing practices (1.88).

\section{Determinants of the adoption of YMT}

This section discusses the factors that affect the adoption of YMT among farmers. The result of the Probit analysis to investigate the determinants of adoption presented in Table 9, reveals that the frequency of extension contact $(\beta=0.209)$ and membership of farmer-group $(\beta=-0.562)$ significantly 
Table 7: Reasons for the non-adoption of YMT $(n=85)$.

\section{Reasons}

Poor knowledge and skill

High cost of labour

More expensive than other methods.

Time consuming

It failed when I tried it

Poor training in YMT

The produce is small-sized

Tedious technology

Relevant to large farms

Poor comparative advantage

Believe poduce from YMT will not produce planting materials

I am not interested in new information

The benefit of adopting YMT is not appealing

YMT not compatible to our farming system

S.A F (\%) AF (\%) DF(\%) S.D F (\%) Score MS Rank

$\begin{array}{lllllll}23(27.1) & 41(48.2) & 15(17.6) & 6(7.1) & 251 & 2.95 & 1 \text { st } \\ 25(29.4) & 35(41.2) & 21(24.7) & 4(4.7) & 251 & 2.95 & 1 \text { st } \\ 19(22.4) & 43(50.6) & 20(23.5) & 3(3.5) & 248 & 2.92 & 3 \text { rd } \\ 20(23.5) & 40(47.1) & 22(25.9) & 3(3.5) & 247 & 2.91 & 4 \text { th } \\ 22(25.9) & 36(42.4) & 23(27.1) & 4(4.7) & 246 & 2.89 & 5 \text { th } \\ 19(22.4) & 42(49.4) & 19(22.4) & 5(5.9) & 245 & 2.88 & 6 \text { th } \\ 18(21.2) & 37(43.5) & 26(30.6) & 4(4.7) & 239 & 2.81 & 7 \text { th } \\ 19(22.4) & 35(41.2) & 27(31.8) & 4(4.7) & 239 & 2.81 & 7 \text { th } \\ 16(18.8) & 40(47.1) & 20(23.5) & 9(10.6) & 233 & 2.74 & 9 \text { th } \\ 18(21.2) & 38(44.7) & 13(15.3) & 16(18.8) & 228 & 2.68 & 10 \text { th } \\ 14(16.5) & 33(38.8) & 34(40) & 4(4.7) & 227 & 2.67 & 11 \text { th } \\ 13(15.3) & 32(37.6) & 34(40) & 6(7.1) & 222 & 2.61 & 12 \text { th } \\ 13(15.3) & 29(34.1) & 38(44.7) & 5(5.9) & 220 & 2.59 & 13 \text { th } \\ 0(0) & 7(8.2) & 59(69.4) & 19(22.4) & 158 & 1.86 & 14 \text { th }\end{array}$

Source: Field Survey, 2018. MS (Mean score); SD: Strongly Disagreed; D: Disagreed; A: Agreed; SA: Strongly Agreed.

Table 8: Constraints to the use of YMT $(n=120)$.

\section{Constraints}

High production cost

Poor availability and quality of dust and insecticide

Poor training on the planting technique

Poor skill and knowledge of minisett preparation

Heavy demand on time leading to late planting at times

Poor market due to discrimination against produce from YMT

High labour demand in miniset

Poor compatibility with existing practice

Source: Field Survey, 2018.

influenced the adoption of YMT. The positive coefficient for the frequency of extension implies that more extension contacts the farmers had, the higher their adoption of Yam Mininsett Technology. Also, farmers' adoption of YMT increased with their membership of farmergroups. This result corroborates with the findings of Ilesanmi and Akinmusola (2016) and Omotesho et al. (2012) who reported that extension contact and membership of farmer-group are factors that can determine the level of innovation. However, age, household size, year of schooling, farm size, annual farm income, and farming experience were not significant in predicting the adoption of Yam Minisett Technology.

Relationship between farmers' training need on yam minisett technology and adoption of the technology

This section discusses the correlation between farmers' training need on YMT and adoption of the technology. The results are presented in Table 10.

$\begin{array}{lllllll}\text { NC F (\%) } & \text { NS F (\%) } & \text { S F (\%) } & \text { VS F (\%) } & \text { Score MS } & \text { Rank } \\ 12(10) & 59(49.2) & 18(15) & 31(25.8) & 308 & 2.57 & 1^{\text {st }} \\ 29(24.2) & 61(50.8) & 21(17.5) & 9(7.5) & 250 & 2.08 & 2^{\text {nd }} \\ 37(30.8) & 53(44.2) & 22(18.3) & 8(6.7) & 241 & 2.01 & 3^{\text {rd }} \\ 41(34.2) & 43(35.8) & 32(26.7) & 4(3.3) & 239 & 1.99 & 4^{\text {th }} \\ 44(36.7) & 40(33.3) & 30(25) & 6(5) & 238 & 1.98 & 5^{\text {th }} \\ 29(24.2) & 44(36.7) & 30(25) & 17(14.2) & 233 & 1.94 & 6^{\text {th }} \\ 44(36.7) & 49(40.8) & 21(17.5) & 6(5) & 229 & 1.91 & 7^{\text {th }} \\ 40(33.3) & 54(45) & 23(19.2) & 2(1.7) & 225 & 1.88 & 8^{\text {th }}\end{array}$

Table 9: Result of probit analysis of determinants of adoption of the yam minisett technology.

\begin{tabular}{|c|c|c|c|c|}
\hline Variables & $\begin{array}{l}\text { Param- } \\
\text { eters }\end{array}$ & $\begin{array}{l}\text { Coeffi- } \\
\text { cient }\end{array}$ & $\begin{array}{l}\text { Standard } \\
\text { error }\end{array}$ & t-value \\
\hline Constant & $\mathrm{B}_{0}$ & -0.015 & 0.545 & -0.027 \\
\hline Age & $\mathrm{B}_{1}$ & -0.001 & 0.013 & -0.076 \\
\hline Household size & $\mathrm{B}_{2}$ & -0.047 & 0.042 & -1.119 \\
\hline Years of schooling & $\mathrm{B}_{3}$ & 0.002 & 0.021 & 0.095 \\
\hline $\begin{array}{l}\text { Frequency of extension } \\
\text { contact }\end{array}$ & $\mathrm{B}_{4}$ & $0.209^{* * * *}$ & 0.095 & 2.200 \\
\hline Farm size & $\mathrm{B}_{5}$ & 0.039 & 0.045 & 0.867 \\
\hline Annual farm income & $\mathrm{B}_{6}$ & 0.001 & 0.001 & 1.000 \\
\hline $\begin{array}{l}\text { Membership of farm- } \\
\text { er-group }\end{array}$ & $\mathrm{D}_{1}$ & $0.562^{* * * *}$ & 0.226 & 2.487 \\
\hline
\end{tabular}

Source: Field Survey, 2018. Significant ${ }^{*}$ *** $5 \%$.

Table 10: Relationship between farmers' training need on yam minisett technology and adoption of the technology.

\section{Variable}

r-value p-value

Farmers' training need

$-0.224^{*-\cdots} \quad 0.001$

correlation is significant at the 0.05 level (2-tailed). 
Results of correlation analysis between farmers' training need on YMT and adoption of the technology reveals that there was an inverse relationship between farmers' training need and adoption of YMT. The result indicates that poor adoption of the technology can be attributed to poor training on the YMT. This conclusion is reached, based on the fact that farmers with higher training needs are the ones with the lower rates of adoption. This means that adoption can be enhanced by exposing farmers to more training on the technology.

\section{Conclusions and Recommendations}

The study concluded that in spite of the benefits offered by the YMT and the fact that it had been introduced to farmers in the state for over a decade, its adoption was only fair and significantly influenced by the frequency of extension contact and farmers' membership of farmer-groups. High cost involved in using the technology, poor technological knowhow and wrong perception of the technology among the farmers were the broad reasons for non-adoption of the technology. Farmers who had adopted the technology decry its high cost and require training in its use.

Based on the findings, the following recommendations are put forward;

1. The YMT and other such innovations need to be backed with adequate follow-up and training of farmers to guarantee continuous use.

2. There is need for more awareness creation and extension education on the YMT and other innovations to forestall wrong perception and hence negative attitude from the end users.

3. There is a need for increase in the frequency of extension visits to farmers in the study area.

4. It is important that accompanying materials for the use of innovations such as the minisett dust and insecticides should be made readily available to farmers when technologies are being deployed.

5. Effort should be made to make innovations as compatible as possible with farmers' existing practices so as to aid their acceptance.

\section{Novelty Statement}

This manuscript identified issues of innovation compatibility, cost and end users' perception as major challenges to the adoption of technology in
Kwara State. It also reiterates the role of training in innovation diffusion.

\section{Author's Contribution}

OKF conceptualised and Supervised the overall research work. AAV carried out the field survey and report write-up. AFA carried out data entry and analysis and report write-up. DAO was involved in field survey, report writing and editing.

\section{Conflict of interest}

The authors have declared no conflict of interest.

\section{References}

Aighewi, B.A., R. Asiedu, N. Maroya and M. Balogun. 2015. Improved propagation methods to raise the productivity of yam (Dioscorea rotundata Poir.). Food Secur., 7: 823-834. https://doi.org/10.1007/s12571-015-0481-6

Balogun, M.O., N. Maroya and R. Asiedu. 2015. Status and prospects for improving yam seed systems using temporary immersion bioreactors. Afr. J. Biotechnol., 13(15): 1614-1622. https:// doi.org/10.5897/AJBX2013.13522

Bolarinwa, K.K. and J.O. Oladeji. 2009. Adoption and relevance of yam minisetttechnology practices to farmers indigenous practices in rain forest and derived savannah zones of Nigeria. J. Appl. Sci. Res., 5(12): 2461-2465.

Borich, C.D., 1980. A needs Assessment Model for Conducting Follow up Studies. J. Teach. Edu., 31(3): 39-42. https://doi. org/10.1177/002248718003100310

Federal Government of Nigeria, 2017. Economic growth recovery plan. Retrieved from https://yourbudgit.com/wp-content/ uploads/2017/03/Economic-RecoveryGrowth-Plan-2017-2020.pdf

FAO, 2006. Production year book. FAO, Rome.

FAO, 2018. National gender profile of agricultural an rural livelihood, Nigeria. Retrieved from http://www.fao.org/3/CA0818EN/ca0818en. pdf

Ilesanmi, R.Y. and O. Akinmusola. 2016. Factors limiting the yam minisett technique adoption: A review. Agric. Rev., 37(3): 213-220.

International Fund for Agricultural Development (IFAD). 2012. Enabling poor rural people to overcome poverty in Nigeria. Retrieved from 
http://www.ifad.org/operations/projects/ regions/pa/facesheet/ng.pdf.

Kwara State Agricultural Development Project, 2005. Annual bulletin 2005.

Maroya, N., M. Balogun and R. Asiedu. 2014. Seed Yam production in aeroponics system: A novel technology.International Institute for Tropical Agriculture, Ibadan, Nigeria. YIIFSWA Working Pap. Ser. 2: 1-22.

Mohammad-Lawal, A., K.F. Omotesho, O.F. Adekola and D. Adekunle. 2014. Assessment of Land Management Practices in Food Crops Production among Small Scale Farmers in Kwara State, Nigeria. Int. J. Agric. Manage. Dev. 4(2): 105-116.

National Population Census (NPC).2016. National population census. National population commission, provisional census figure of the 2006 National census for Kwara State, Nigeria.

National Cereal Research Institute NCRI, 2018. Brief about national cereal research institute, Badegi. Retrieved from https://www. ncribadeggi.org.ng/index.php/about-us/briefhistory

National Universities Commission (NUC), 2019. List of Universities in Nigeria. Retrieved from http://nuc.edu.ng/

Nnadi, F.N and Akwiwu, C.D. 2007. Farmers Discontinuance decision behaviours of yam minisett technology in Imo State, Nigeria. Int. J. Agric. Rur. Dev. 9(I): 85-88. https://doi. org/10.4314/ijard.v9i1.2671

Odinwa, A.B., N. Ali, I. Abali, A.A. Ahiskwo and A.N. Odinwa. 2011. Economic viability of yam mini-sett production and the problems affecting mini-sett enterprise in Northern River State, Nigeria. Med. J. Soc. Sci. 2(4): 115-121.

Oguntade, A.E., O.A. Thompson, and T. Ige. 2010. Economics of Seed Yam Production using Minisett Technique in Oyo State, Nigeria.
Field Actions Science Reports, 4: 1-10. Retrieved from https://journals.openedition. org/factsreports/659

Omotesho, O.A and A. Falola. 2014. National agricultural research system in africa in digging deeper: Inside Africa's agricultural, food and nutrition dynamics (eds) Akinyoade, A., Klaver, W. Soeters, S. and Foeken, D. Koninklijke Brill nv, Leiden, The Neitherlands. https://doi. org/10.1163/9789004282698_012

Omotesho, O.A., A. Falola, A. Muhammad-Lawal and A. Oyeyemi. 2012. Comparative analysis of the performances of adopters and non-adopters of yam minisett technology in Kwara State, Nigeria. Int. J. Agric. Rur. Dev. 15(3): 13351341.

Osunde, Z.D., 2008. Minimising Post-harvest losses in yam (Dioscorea sp): Treatments and techniques. Chapter 12 from using food science and technology to improve nutrition and promote national development, Robertson, G.C and Lupien, J.R (Eds). Int. Union Food Sci. Technol. pp. 1-9.

Rogers, E.M. 1995. Diffusion of innovations (4th ed.). Free Press, New York.

Rogers, E.M., 2003. Diffusion of innovations ( $5^{\text {th }}$ ed.). Free Press, New York.

Saror, S., E.C. Ogbanje and Y.A. Olu. 2009. Disconnected adoption of agricultural innovations among small-scale soy bean farmers in gboko local Government area of Benue state. Proc. $43^{\text {rd }}$ Annu. Conf. Agric. Soc. Nigeria. pp. 565-569.

Simtowe, F., 2011. Determinants of agricultural technology adoption: The case of improved pigeon pea varieties in Tanzania.

Uaiene, R.N., C. Arndt and W.A. Masters. 2009. Determinants of agricultural technology adoption in mozambique. Discuss. Pap. No. 67E. January, 2009. 